\title{
Surveying the Changing Landscapes of Late-to-Post-Pleistocene Epirus (NW Greece)
}

\author{
Eugenia Adam $^{1}$, Maria Ntinou ${ }^{2}$, Paraskevi Yiouni ${ }^{1}$ and Dimitris Kontogiorgos ${ }^{*, 2}$ \\ ${ }^{I} I B^{\prime}$ Ephorate of Prehistoric and Classical Antiquities, Greek Ministry of Culture, 6, $25^{\text {th }}$ March Square, Ioannina, \\ Greece \\ ${ }^{2}$ Wiener Laboratory, American School of Classical Studies at Athens, 6 Souidias Str., 10676 Athens, Greece
}

\begin{abstract}
This report presents the results of a survey in inland Epirus (NW Greece). Although visibility for ground survey was in general low due to the abandonment of fields and the re-growth of thick vegetation cover, various locations suitable for further investigation have been identified. The artefacts recovered in the investigated areas represent both prehistoric and historical cultural periods. The cultural attribution of the artefacts is supported by radiocarbon dates obtained from selected charcoal samples.
\end{abstract}

Keywords: Survey, Post-Pleistocene, Radiocarbon, Epirus (NW Greece).

\section{INTRODUCTION}

The entire region of Epirus, including the hinterland of the Ioannina prefecture on which this research project focuses, has already been subject to surveys and excavations. This intensive multidisciplinary research on the prehistory of the region, initiated in the 1960's and continued until the late 1990's, produced an impressive archaeological record ranging from the Lower Palaeolithic to the Neolithic, which is still being enriched with new data. These projects have set the pace for a multidisciplinary approach to archaeological landscape reconstruction and evaluation that would shed light on its influence on the decision-making of local populations in the past [1].

Still, the Palaeolithic is over-represented in the archaeological record of Epirus, with only little evidence for the post-palaeolithic periods; indeed the Mesolithic and the Neolithic are represented by very few finds. When considering the reasons for this, we should not overlook the fact that fieldwork in the area on post-palaeolithic prehistoric periods has so far been very limited. This is true both for the whole of Epirus and for its hinterland, which is the focus of the present research project.

This scarcity of data on the Late Pleistocene to Early Holocene human activity on Epirus is attributed to environmental factors closely related to the landscape particularities (mountains, restricted lowland interior basins, erosion, and badlands) of the region.

Another critical factor to keep in mind when considering the prehistory of inland Epirus is, possibly, the different nature of the Neolithic and the Bronze Age in this region, which could deviate from far better explored and recorded patterns, as is for example the adjacent Thessalian Neolithic.

*Address correspondence to this author at the Wiener Laboratory, American School of Classical Studies at Athens, 6 Souidias Str., 10676 Athens, Greece; Tel: (+30)2130002400: Fax: (+30) 2107250584:

E-mail: mitsaraskonto@hotmail.com
Therefore, subsistence strategies, habitation patterns, community organization, and material culture should be reconsidered in relation to the environmental peculiarities and isolation of the area.

Additionally, the Mesolithic substrate of the area, for which there are but a few testimonies, needs to be defined spatially and temporally and evaluated in relation to the appearance of farming economies [2].

This approach to the later prehistory of the area led to the present research project, which focuses initially on revisiting the areas in the Ioannina prefecture for which isolated postPalaeolithic prehistoric finds had been reported in order to re-evaluate the representation of these chrono-cultural periods in the hinterland of Epirus.

The survey program expanded over an area of some 3000 hectares and was conducted in 2008/2009, after the required permit of the Greek Ministry of Culture was obtained. The surveyed areas, mostly plains or foothills, were the regions between the villages Asfaka-Protopappas, Parakalamos-Mazaraki and Pesta (Fig. 1). The first two are located in the north - northwestern part of the Ioannina district, and the third in the southwest.

The areas were chosen because of their agricultural nature, their location near major water supplies (lakes, rivers) and their archaeological record. The results of this research are presented.

\section{METHOD AND RESULTS}

\subsection{Method}

All areas were initially visited and evaluated. In all ground visibility was very low as a result of the abandonment of agricultural practices that has left previously cultivated fields unattended, leading to the growth of a thick low vegetation mantle. Additionally, lack of ploughing diminished the possibility of locating archaeological data (artefacts or structures). The lack of good visibility, however, was not 


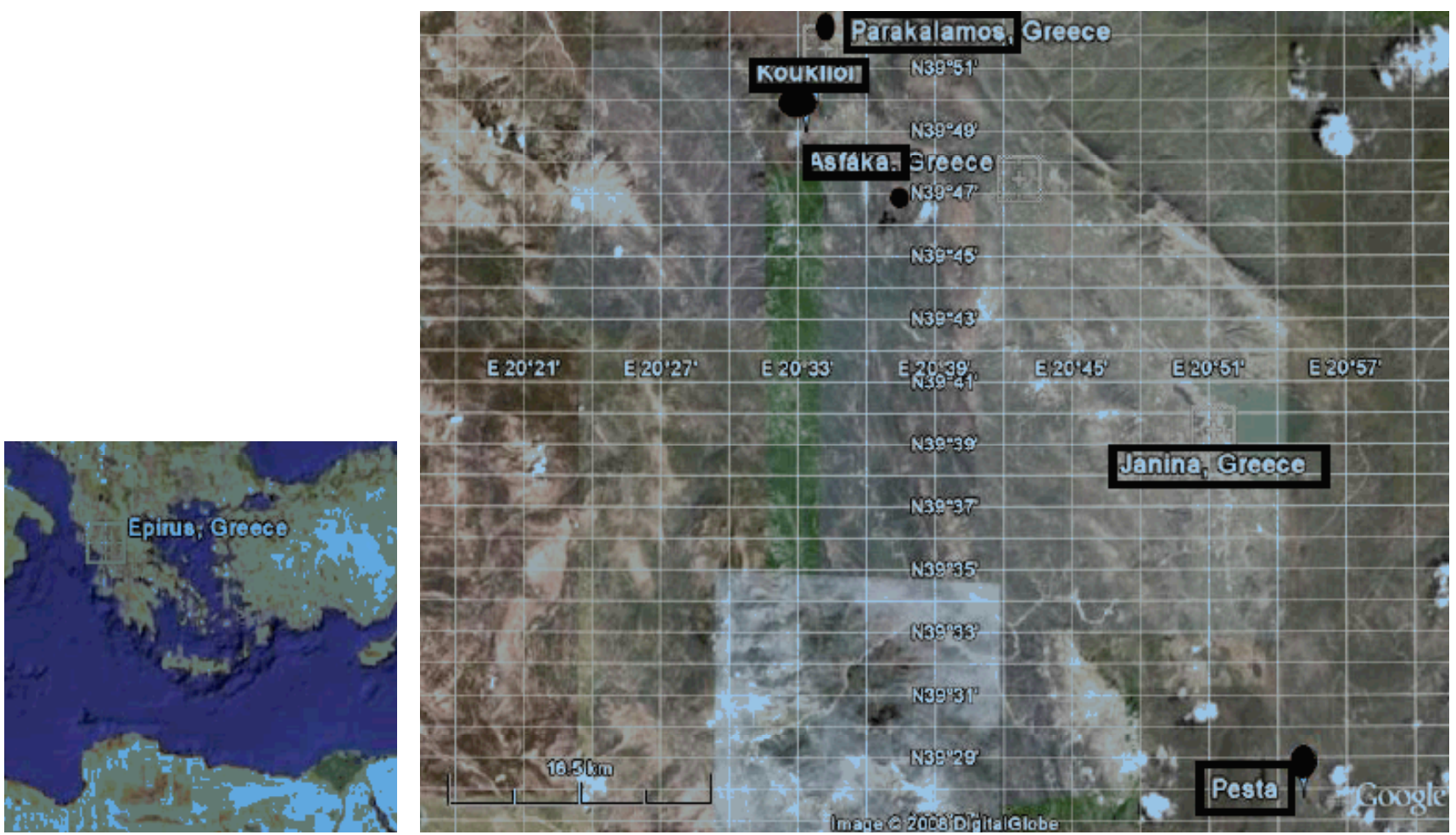

Fig. (1). The location of the surveyed areas (Google Map-modified).

a major drawback in our survey since our intention is to revisit the area.

Nevertheless, we did find various locations within each area that could serve the purposes of our project, i.e. exposed sections of drainage channels (Asfaka-Protopappas area), eroded slopes (Parakalamos-Mazaraki area) and occasionally cultivated fields (Pesta). Subsequently, our research focused on these locations.

The finds were not collected systematically. Their presence was recorded and just a few of them (the most diagnostic whenever possible) were removed; the majority were left in situ for future work.

The location of finds and sections was recorded with GPS using the national projection system EGSA'87 (Greek Grid Reference System).

Wood charcoal samples were collected from exposed channel sections and were submitted for AMS dating to BETA Analytic Inc., Miami, Florida USA.

\subsection{Results by Site}

\subsubsection{Asfaka-Protopappas}

The surveyed area lies within the territory of the former Lapsista Lake that was drained in the '60's and since then has been used mainly for corn cultivation (Fig. 2). Lapsista lake was once connected to Lake Pamvotis by underground channels. In the Pleistocene probably the two lakes formed a single, larger one, occupying the whole of the Ioannina basin [3]. In the area a limited stratified horizon with prehistoric pottery was located in the 1960's by E.S. Higgs. A radiocarbon date of $7380 \pm 240 \mathrm{BP}$ was obtained at the time [4]. This constitutes the earliest information on human activity in the area.

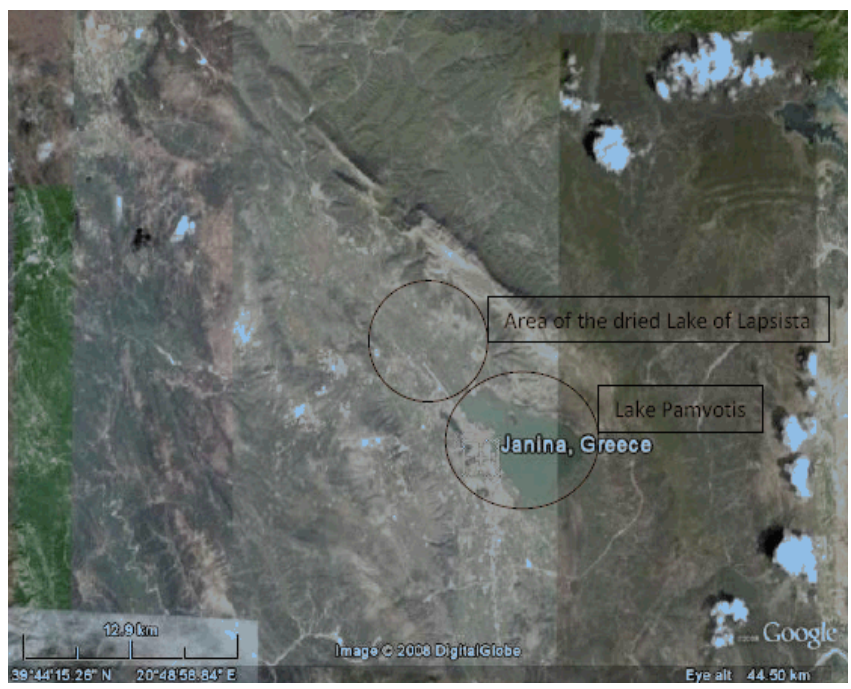

Fig. (2). The location of the former Lapsista Lake in the Ioannina basin(Google Map-modified).

In modern times and before drainage the area flooded seasonally, thus creating a rich biotope. Water emanated from the so-called "anavres" (underground springs) [5] three of which still exist today, the most visible one located close to the village of Asfaka that was the focus of our research (Fig. 3).

The broader area was surveyed and a number of sections formed in the drainage channels and along the deep ditches recently cut for pipeline installation, were noticed. We were eventually able to distinguish four sections with artefactbearing deposits (pottery fragments, lithics and, in one occasion, bones). The sections were numbered from I to IV; the 
first two (I and II) are located near the village of Asfaka, very near the "anavra" and the other two are situated close to the foothills of the limestone massif to the north.

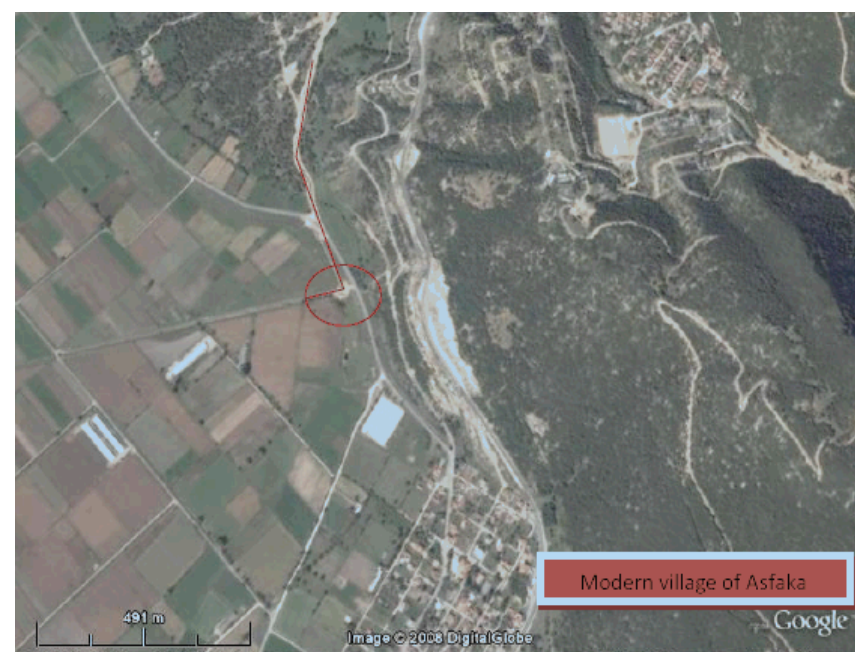

Fig. (3). The broader area of the village of Asfaka. Notice the Anavra to the north-west of the village(Google Map-modified).

Section I (spot A on the map, 002-20-801, 044-08-005, $459 \mathrm{~m}$ asl) (Figs. 4 and 5) was created by the opening of a channel parallel to the "anavra". The section showed stratified layers of silty-clay intercept by gravel layers (Fig. 6). Much of the material in those gravel layers was natural chert. Pottery fragments and wood-charcoals were observed along the section. Various charcoal samples were collected and two of them were submitted for AMS dating. Surface artefacts and pottery fragments were collected from the broader area; they probably originated from the sediments removed while opening the channel.

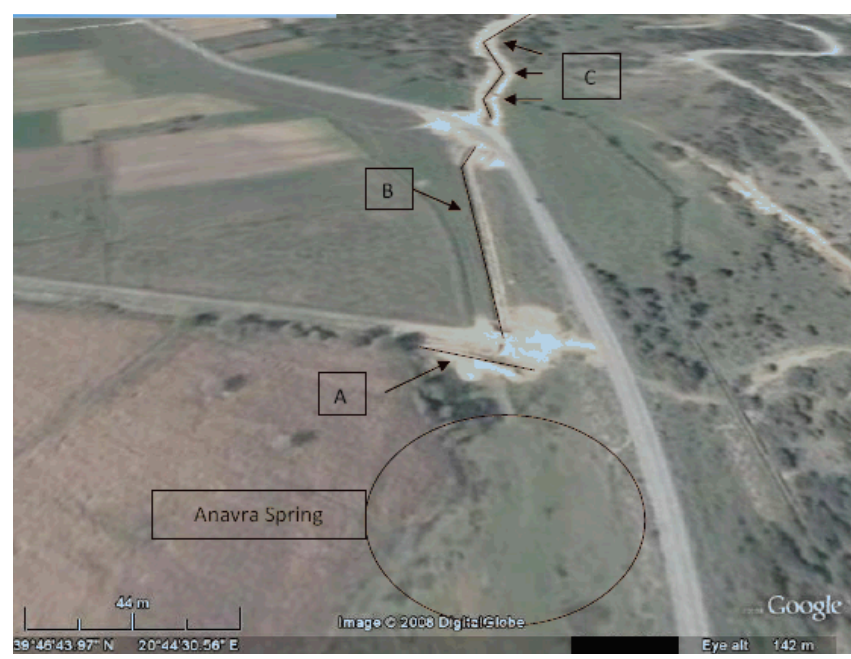

Fig. (4). The Anavra and the two channels where stratigraphic sections I and II had been exposed (Google Map-modified).

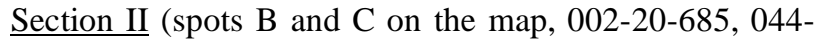
08-092, 463m asl) (Figs. 4 and 5) was also created by opening a channel perpendicular to the "anavra" and leading towards the hilly flanks below the main road. This section did not show any stratification, and the finds, artefacts and ecofacts alike, were scattered in a silty clay sediment (Fig. 7).
Pottery fragments were observed and in one occasion animal bones too. Wood-charcoal fragments were collected and one of them from the lower part of the section was submitted for AMS dating.

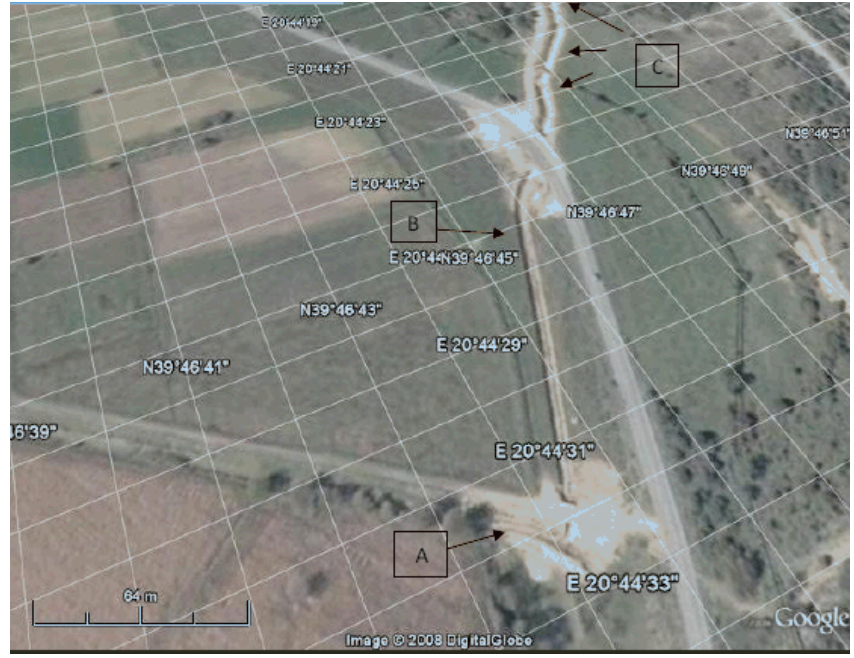

Fig. (5). Deatailed location of Sections I (A) and II (B and C) (Google Map-modified).

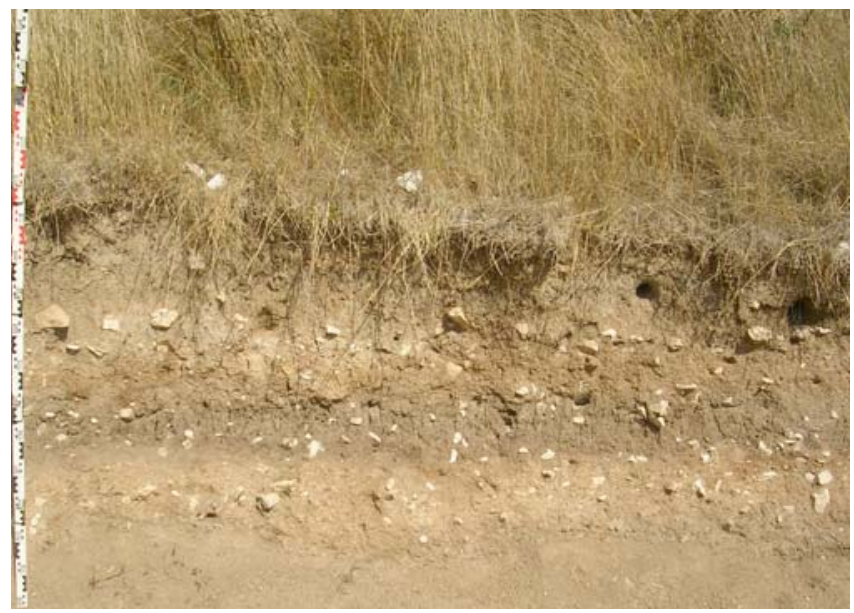

Fig. (6). Anavra Section I.

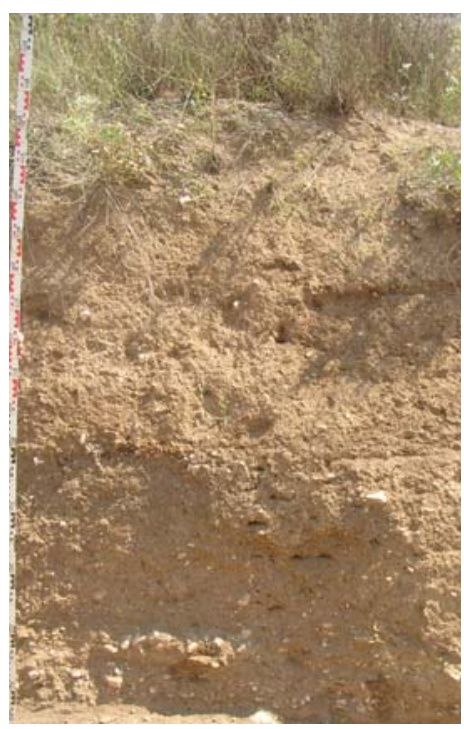

Fig. (7). Anavra Section II. 
Sections III and IV (002-18-221, 044-07-525, 473m asl and 002-17-680, 044-06-474, 463m asl, respectively) (Figs. 8 and 9) were created by digging a ditch for the water pipeline. In both sections we observed a gravel horizon that included a few small pottery fragments and lithics. In Section III the deposits above the gravel horizon included various pottery fragments.

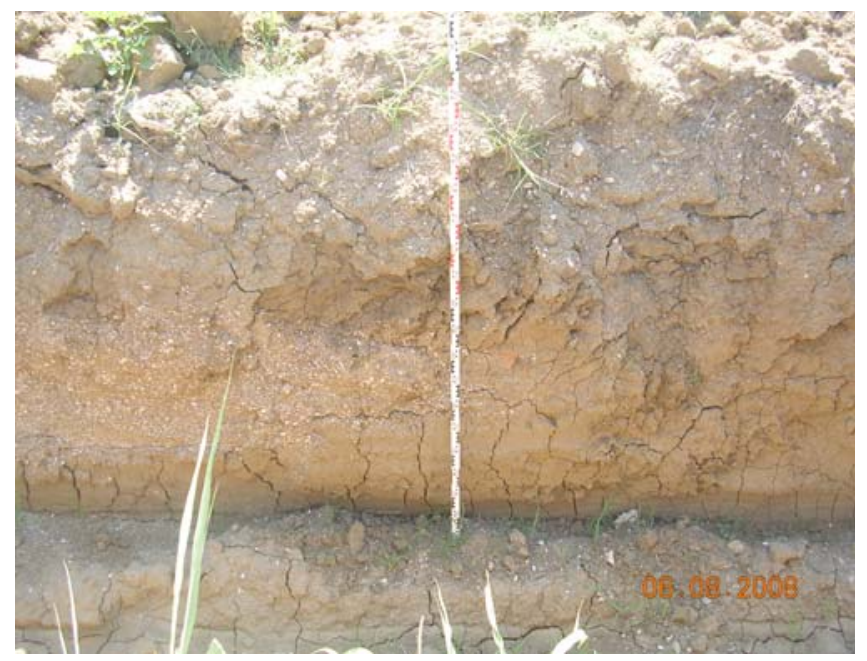

Fig. (8). Anavra Section III.

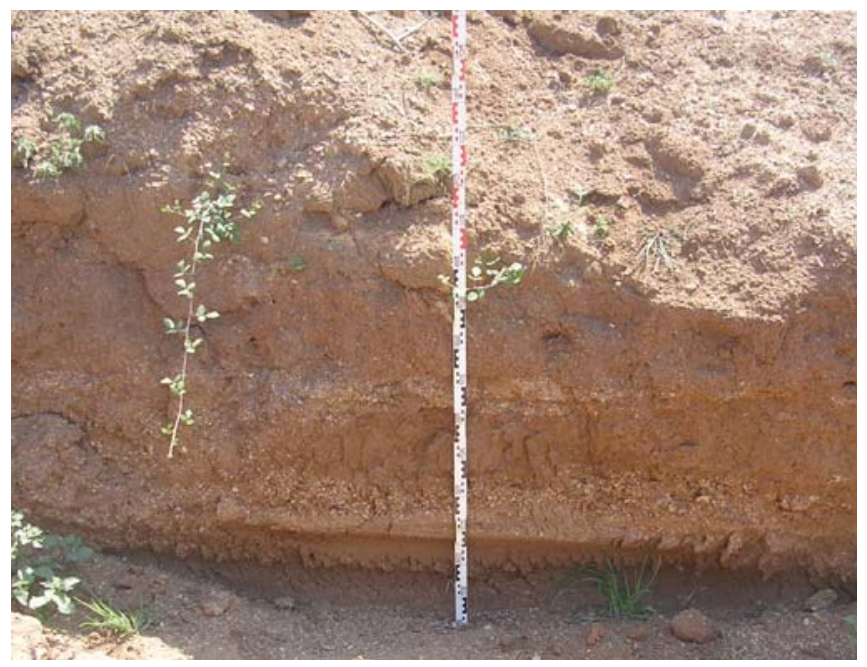

Fig. (9). Anavra Section IV.

In the Asfaka area, the alternation of gravel and silty-clay horizons in the sections seems to indicate that the area was situated at the borders of the lake, probably affected seasonally by higher water tables but in general being dry land. These characteristics are in agreement with a concentration of artefacts in the Asfaka area and the north-northwestern borders of the former lake.

\subsubsection{Parakalamos-Mazaraki}

The village of Parakalamos is located close to the Doliana basin where the remains of a prehistoric habitation dated to 3600-3100 BC were excavated in the 1990's [6]. The area around Mazaraki village has yielded sporadic surface finds attributed to the Late Stone Age and the Bronze Age $[7,8]$.
The eastern part of the surveyed area comprises intensively cultivated corn fields, surrounded by thick deciduous woodland. The locations with good visibility are situated in the western-south western part of the area. These are Agios Ioannis, where dense pottery scatters were observed, and Nisia where stone artefacts were located on eroded slopes around a small lake (Fig. 10). The "Nisia" location (002-06915, 044-10-846, 375m asl) exhibits geomorphological similarities (Fig. 11) with Kokkinopilos [9] and the finds recovered here support this view.

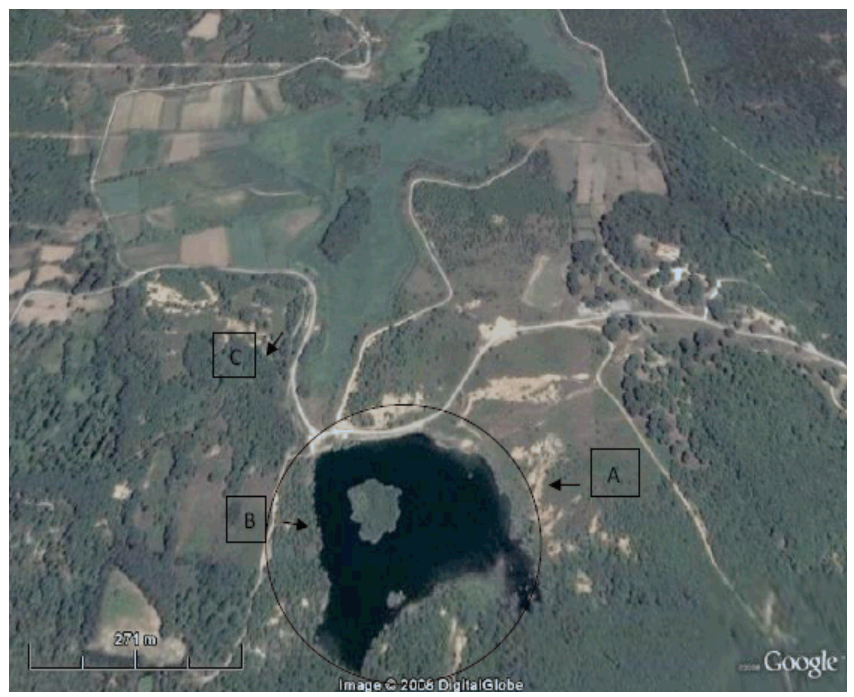

Fig. (10). Loci at Nisia and Ag. Ioannis(Google Map-modified).

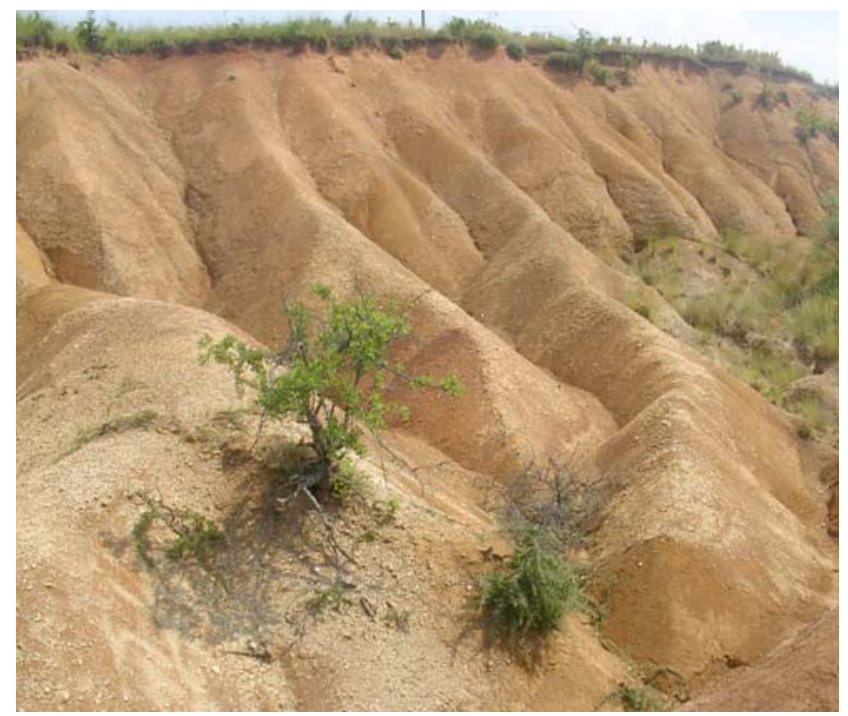

Fig. (11). Parakalamos, "Nisia".

\subsubsection{Pesta}

The area of Pesta has yielded important architectural remains of the late antiquity, and surface finds of the Stone and Late Bronze Age [7]. Located near the north-to-south corridor of the Louros gorge, provides a contrast with the other three target-areas that are mostly located in flat basins.

As in the case of Parakalamos, the Pesta area too was severely overgrown due to absence of cultivation and animal husbandry, and yielded very poor results. Nevertheless, the 
recent location in the area by one of the authors [10] of a large number of stone artefacts of Palaeolithic character, among which a few attributable to the Neolithic period, indicates that this region is worth exploring further.

\section{THE FINDS}

\subsection{Lithics (Table 1)}

A third of the 45 in total stone artifacts recovered during the survey can be attributed to late prehistoric times: one bladelet core and a core fragment from Anavra 3 and four artifacts (debitage, core and retouched piece) from Anavra 1 and Anavra 2 could be assigned to the Late Neolithic/Bronze Age. The lithics from the Parakalamos area ("Nisia") are of Palaeolithic character and can be compared to surface finds from red-earth deposits in the Louros area (i.e. Kokkinopilos etc). The Anavra lithics are also interesting because their raw materials are not common in the Palaeolithic and Mesolithic assemblages of Epirus.

\subsection{Pottery (Table 1)}

In all, 50 sherds were collected. Their majority consists of body sherds, with only four (4) bases, four (4) lugs and a single rim-sherd, while eight (8) sherds belong to ceramic tiles. The pottery ranges chronologically from prehistoric to historic times.

Prehistoric sherds, dated to the Bronze Age, were located at Asfaka (Anavra location). A number of sherds from locations Anavra 1, Anavra 2, Anavra 3 could be assigned to the Bronze Age on the basis of fabric texture, surface treatment and firing.

In all cases, vessels were hand-made and fired in conditions supporting incomplete oxidation, resulting in dark cores and surfaces with firing clouds. Such characteristics are compatible with open-firing of the pots.

Considering the paucity of the prehistoric ceramic material from Epirus - in clear contrast with the situation encountered in the rest of the Greece - the sherds collected during the survey are indicative of the importance of the area of Asfaka, and its surroundings.

Ceramic material attributed to historical times was collected from other locations in the Asfaka area, as well as from Protopappas and Parakalamos. Vessels are finetextured, wheel-made, with red- or grey- colored fabrics. Unfortunately, the fragmentation of the finds prohibits their assignment to specific vessel-types or to exact chronological periods.

Table 1. Finds by Location

\begin{tabular}{|c|c|c|c|c|c|c|}
\hline & Area & Location & Stone & Pottery & Total & Date/Period \\
\hline 1 & Asfaka & Anavra 1 , & 3 & - & 3 & Neolithic / Bronze Age \\
\hline 2 & Asfaka & Anavra 2, & 5 & 2 & 7 & Neolithic / Bronze Age \\
\hline 3 & Asfaka & Anavra 3 , & 3 & 2 & 5 & Neolithic / Bronze Age \\
\hline 4 & Asfaka & Anavra 4, canal & 5 & 8 & 13 & Neolithic / Bronze Age \\
\hline 5 & Asfaka & Anavra 5, Section I & 5 & 8 & 13 & Bronze Age to Early Iron Age \\
\hline 6 & Asfaka & $\begin{array}{c}\text { Anavra 6, Section I, } \\
\text { spoil heap }\end{array}$ & - & 5 & 5 & Historical times \\
\hline 7 & Asfaka & $\begin{array}{l}\text { Anavra } 7, \text { Section I, } \\
\text { organic lens }\end{array}$ & - & 1 & 1 & Bronze Age \\
\hline 8 & Asfaka & $\begin{array}{l}\text { Anavra } 8, \text { Section II, } \\
\text { cleaning }\end{array}$ & - & 9 & 9 & Historical times \\
\hline 9 & Asfaka & $\begin{array}{c}\text { Anavra } 9 \text {, Section II, } \\
\text { talus }\end{array}$ & - & 1 & 1 & Historical times \\
\hline 10 & Asfaka1 & Section III & 5 & - & 5 & Bronze Age? \\
\hline 11 & Asfaka 2 & Section III & - & 8 & 8 & Historical times \\
\hline 12 & Asfaka 3 & Section IV & 4 & 5 & 9 & Historical times \\
\hline 13 & Parakalamos & "Nisia" 1 & 10 & - & 10 & Stone Age \\
\hline 14 & Parakalamos & "Nisia" 2 & 3 & - & 3 & Stone Age \\
\hline 15 & Parakalamos & "Nisia" 3 & 5 & - & 5 & Stone Age \\
\hline \multirow[t]{2}{*}{16} & Parakalamos & Ay. Ioannis & - & 2 & 2 & Historical times \\
\hline & TOTALS & & 45 & 51 & 96 & ------- \\
\hline
\end{tabular}


Table 2. Asfaca Sections I and II: AMS Dates

\begin{tabular}{|c|c|c|c|c|c|c|}
\hline Sample N $^{\mathbf{2}}$ & Section & Depth & Radiocarbon Age & Cal BC/AD & Charcoal Identification & Lab \\
\hline \hline ANV1 & I & $0.67 \mathrm{~m}$ & $1460 \pm 40 \mathrm{BP}$ & Cal AD 540-650 & Angiosperm & Beta-248661 \\
\hline ANV2 & I & $0.35 \mathrm{~m}$ & $2990 \pm 40 \mathrm{BP}$ & Cal BP 1390-1120 & Carpinus orientalis & Beta-248662 \\
\hline ANV3 & II & $0.89 \mathrm{~m}$ & $2920 \pm 40$ BP & Cal BP 1270-1010 & Carpinus orientalis & Beta-248663 \\
\hline
\end{tabular}

\section{RADIOCARBON DATING AND PALAEOBOTANI- CAL EVIDENCE}

Three wood charcoal fragments selected from the Asfaka Sections I and II were AMS dated and the results are presented in Table 2 . Given the availability of wood charcoal from both sections I and II it was considered preferable to date this type of material. Fragmented animal bones were observed at the bottom of Section II from where the Anavra 3 originated. Unfortunately, no animal bones were found in Section I. If such material was available from that section it would have also been selected for dating in order to clarify the problematic reversal of dates from section.

The results from Section I, in particular the inverted dates from samples ANV 1 and 2, indicate re-working of the sediments despite the fact that clearly stratified horizons were observed in that section. What's more, the artefacts recovered from section I are also attributed to both prehistoric and historical periods. Our hypothesis is that the materials in Section I were transported and re-deposited by water action. On the other hand, the Late Bronze Age dates from samples ANV 2 (Section I) and ANV 2 (bottom of Section II) are in agreement with the pottery samples from Anavra and the lithics from Section III (Table 1), thus suggesting that human activity in the area during that period was significant.

Another aspect of the dated charcoal fragments is that ANV 2 and ANV 3 -the ones that provided the Late Bronze Age dates- were identified as wood of the species Carpinus orientalis. The presence of this species in the area during the second millennium $\mathrm{BC}$ can be related to a broader vegetation phase of the pollen record of Epirus, initiated at around 5000 BP and characterised by the steep increase of Carpinus [3, $11,12]$.

This plant taxon is greatly favoured by open canopy and grazing animals; its presence in the Holocene vegetation can be a result of both natural factors (soils, species competition and slow pace of re-expansion after the Pleistocene) and human activities. The identification of the species and its dating to the Late Bronze Age could therefore be associated with the presence in the area of farming communities from as early as the Neolithic; their farming activities could have caused Carpinus orientalis to become a prominent feature in the vegetation of the area.

\section{CONCLUSIONS}

This research in the Epirotic hinterland, led to the following conclusions:

- $\quad$ The targeted area presents in general low visibility for ground survey due to the abandonment of the fields and the subsequent growth of a thick vegetation cover. These accounts for the small number of find locations in a relatively large terrain.

- $\quad$ The most productive survey procedure in these areas proved to be the detailed examination of sections and profiles cut by natural channels, artificial ditches and eroded gullies. Every time such features were detected it was possible either to identify and collect artefacts or to make useful observations concerning the sedimentary horizons and their stratification in the area under study.

- The cultural attribution of the artefacts recovered in the investigated areas indicated both prehistoric and historical periods. The same conclusion has been drawn from radiocarbon dates on selected wood charcoal samples.

- $\quad$ Further field research on post-Palaeolithic prehistoric periods in the area should concentrate in the area of Asfaka and the former Lapsista Lake where the occurrence of Bronze Age and possibly Neolithic finds is notable and easier to trace compared to the other areas surveyed by our team.

\section{ACKNOWLEDGEMENTS}

The authors deeply appreciate INST.A.P (Institute for Aegean Prehistory) for generously funding this research project. We also express our deep appreciation to the IB' Ephorate of Prehistoric and Classical Antiquities (Ioannina,Epirus, Greece) for its collaboration and support throughout the period of the survey. Finally, we thank the two anonymous reviewers for their comments on earlier drafts of this paper.

\section{REFERENCES}

[1] Sturdy D, Webley D, Bailey G. The palaeolithic geography of Epirus. In Bailey G, Ed. Klithi: palaeolithic settlement and quaternary landscapes in northwest Greece, Vol 2: Klithi in its Local and Regional Setting, McDonald Institute Monographs, Cambridge 1997; pp. 587-614.

[2] Bailey G, Cadbury T, Galanidou, Kotjabopoulou E. Rockshelters and Open-air sites. In Bailey G, Ed. Klithi: Palaeolithic Settlement and Quaternary Landscapes in Northwest Greece, Vol. 2: Klithi in its Local and Regional Setting, McDonald Institute Monographs, Cambridge 1997; pp. 521-37.

[3] Bottema S. Late quaternary vegetational history of Northwestern Greece. PhD [dissertation], University of Groningen 1994.

[4] Higgs ES, Vita-Finzi C. The Climate, Environment and Industries of Stone Age Greece. Proc Prehist Soc 1966; 32 (2): 1-29.

[5] Koletas S. The lakes of Ioannina and Lapsista. Publication of the Prefecture of Ioannina, Municipality of Pamvotis, Ioannina 2000 (In greek).

[6] Douzougli A, Zachos K. Archaeologikes ereunes stin Ipiro kai sti Leukada, 1989-1990. Ipirotika Chronika 1994; (31): 11-50 (In greek).

[7] Papadopoulos A. The Bronze age in Epirus. Dodoni 1976; 5: 271338 (In greek). 
[8] Andreou H. New prehistoric sites in Epirus. FIGOS 1994; (1): 239 (In greek).

[9] Dakaris SI, Higgs ES, Hey RW. The climate, environment and industries of Stone Age Greece. Proc Prehist Soc 1964; 30(1): 199244.

[10] Adam E. Middle Palaeolithic artefacts from the Pesta area, Prefecture of Ioannina (Epirus, Greece). Arxaiologiko Deltio (Forthcoming).
[11]

Willis KJ. The Late Quaternary vegetational history of northwest Greece: a comparative study of two contrasting areas. New Phytologist 1992; 121: 139-55.

[12] Willis KJ. The vegetational history of the balkans. Q Sci Rev 1994; 13: 769-88.

(C) Adam et al.; Licensee Bentham Open.

This is an open access article licensed under the terms of the Creative Commons Attribution Non-Commercial License (http://creativecommons.org/licenses/by-nc/3.0/) which permits unrestricted, non-commercial use, distribution and reproduction in any medium, provided the work is properly cited. 